Article

\title{
Investigation of Ancient Wall Painting Fragments Discovered in the Roman Baths from Alburnus Maior by Complementary Non-Destructive Techniques
}

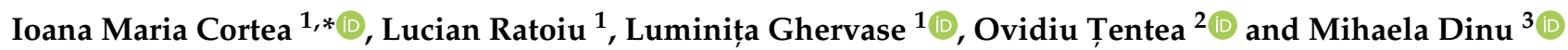 \\ 1 Department of Optoelectronic Methods and Techniques for Artwork Restoration and Conservation, \\ National Institute of Research and Development for Optoelectronics-INOE 2000, 077125 Magurele, Romania; \\ lucian@inoe.ro (L.R.); ghervase@inoe.ro (L.G.) \\ 2 Department of Archaeology, National Museum of Romanian History, 12 Victoriei Ave, \\ 030024 Bucharest, Romania; ovidiu.tentea@gmail.com \\ 3 Department for Advanced Surface Processing and Analysis by Vacuum Technologies, National Institute of \\ Research and Development for Optoelectronics-INOE 2000, 409 Atomistilor St., 077125 Magurele, Romania; \\ mihaela.dinu@inoe.ro \\ * Correspondence: ioana.cortea@inoe.ro
}

check for updates

Citation: Cortea, I.M.; Ratoiu, L.; Ghervase, L.; Tentea, O.; Dinu, M. Investigation of Ancient Wall Painting Fragments Discovered in the Roman Baths from Alburnus Maior by Complementary Non-Destructive Techniques. Appl. Sci. 2021, 11, 10049. https://doi.org/10.3390/

app112110049

Academic Editor: Paola Fermo

Received: 6 October 2021

Accepted: 25 October 2021

Published: 27 October 2021

Publisher's Note: MDPI stays neutral with regard to jurisdictional claims in published maps and institutional affiliations.

Copyright: (c) 2021 by the authors. Licensee MDPI, Basel, Switzerland. This article is an open access article distributed under the terms and conditions of the Creative Commons Attribution (CC BY) license (https:/ / creativecommons.org/licenses/by/ $4.0 /)$.

\begin{abstract}
In this study, several wall painting fragments discovered in the Roman baths from the archeological site Alburnus Maior (Roşia Montană, Romania) were analyzed with the aim to investigate the material composition of both plasters and pictorial layers. Dated from the beginning of the second century AD, these rare findings stand among the oldest examples of preserved decorative polychrome paintings on plaster excavated thus far in the former territory of the Roman province of Dacia. A non-destructive multi-analytical approach based on complementary techniques was considered: Fourier transform infrared (FTIR) spectroscopy, X-ray fluorescence (XRF), X-ray diffraction (XRD), UV fluorescence, and hyperspectral imaging (HSI). The obtained results highlight a common Roman color palette mainly based on naturally occurring earth pigments. Red ochre, yellow ochre, manganese-rich ochres/wads, carbon black, and calcite were identified. A traditional two-layer sequence of plasters was found-arriccio (based on lime and siliceous sands), and intonaco (pure lime). The presence of an organic protein binder, identified via FTIR analysis, and sustained by combined imaging documentation, indicates that the pigments were applied a secco. The obtained results are discussed in relation to previous published data, and they can be considered as valuable archeological indicators that contribute to the understanding of the painting techniques and the materials used in the Roman provinces.
\end{abstract}

Keywords: Roman wall paintings; Roman baths; FTIR; XRF; XRD; hyperspectral imaging; pigments; ochres; Alburnus Maior; cultural heritage

\section{Introduction}

Public baths played an important role in Roman culture and life. A remarkable expression of Roman hydraulic engineering, the use of public baths started to spread towards the end of the third century BC throughout the Roman Empire. Functioning as spaces of great social significance, public baths developed in time into more elaborate complexes (thermae), frequently luxuriously decorated [1-3]. A variety of information exists on the imperial public baths, especially regarding the ones in the Italian Peninsula, while the bathing facilities found in the provinces have started to be studied only more recently [4]. According to the current state of research, within the Roman province of Dacia, almost 40 small baths have been discovered until now, located within the forts (praetorium) as well as in the civilian settlements (extra muros) [4]. Compared to other baths found in Moesia Superior, the ones in Dacia (a frontier province), are, in most cases, modest and relatively early structures built between the second century and first half of the third 
century. Monumental bath structures, which can be associated with an elite residence, are just the ones found at Apulum and at Ulpia Traiana Sarmizegetusa [4,5].

In this paper, several wall painting fragments discovered in the Roman baths from the archeological site Alburnus Maior (Roşia Montană, Romania) [5] were investigated with the help of an array of non- and micro-invasive analytical techniques. Dated from the beginning of the second century $\mathrm{AD}$, these rare findings stand among the oldest examples of preserved decorative polychrome paintings on plaster excavated thus far in the former territory of the Roman province of Dacia. Due to the small number of scientific studies carried out thus far on Roman mural paintings coming from this region [6], this study is considered important as it can offer valuable information not only in terms of materials and painting technique but also in terms of archeological insights.

Roman wall paintings have been intensively studied as early as the nineteenth century, particularly wall painting supports and pigments coming from Rome and Pompeii [7]. Wall painting fragments discovered in other parts of the empire such as Northern Italy, Spain, France, Great Britain, Greece, and Slovenia have also been investigated [8,9]. However, within the province of Dacia, mural decorations have been significantly less studied. This situation can be explained by the fact that in this area, such findings are scarce. Unlike Gaul or Britain (where the Roman wall painting technique was an established tradition developed in workshops), in Dacia, the existing mural paintings were created by craftsmen that were brought from other provinces for specific commissions only [10]. Moreover, the recovery and study of wall paint evidence is also a matter of survival, excavation technique/skill, and, not least, environmental factors which may help natural preservation or not. In the province of Dacia, there are very few examples of preserved Roman paintings, with isolated discoveries often grouped around monumental buildings [10-12]. To this date, there has been only one scientific study published on second century Roman wall painting fragments discovered at the archaeological site of Ulpia Traiana Sarmizegetusa, the findings being associated with the decorations of a domus [6]. A few other papers mention discoveries of Roman mural paintings at Ulpia Traiana [12], Porolissum [13], and Apulum $[10,11]$, but these are mainly archeological studies.

The lack of scientific investigations concerning Roman painted plasters coming from other archeological sites located in the former province of Dacia made us consider new wall painting fragments for analytical investigations-in this case, murals discovered at the Alburnus Maior archaeological site. The aim of this study was to document and characterize the composition of the paint layers and of the plaster used as a substrate and, at the same time, highlight the existing correspondences and differences with previous published data, concerning wall painting fragments from the same period, excavated from other neighboring Roman archeological sites.

To this aim, several wall painting fragments discovered in the Roman baths from Alburnus Maior were analyzed through a minimally invasive methodology based on complementary techniques. Attenuated total reflection Fourier transform infrared (ATRFTIR) spectroscopy was used to obtain qualitative information on the molecular nature of the pigmenting agents, possible organic binders, and the mineralogical composition of the plaster substrate [6,14-16]. X-ray fluorescence (XRF) and X-ray diffraction (XRD) analyses were carried out to obtain additional chemical and mineralogical data on the material composition of the pictorial surfaces and of the plaster $[6,8,14-17]$. UV fluorescence (UVF) and hyperspectral imaging (HSI) were used as non-destructive tools in order to obtain alternative information on the painting technology and working methods $[18,19]$. The capacity of the HSI technique for material identification and mapping was also tested [20]. The results of the performed investigations are expected to highlight the general color palette used at Alburnus Maior, in order to provide details on the working methods, choice of materials, and possible raw material sources used by local craftsmen. 


\section{Materials and Methods}

\subsection{Archeological Background and Wall Painting Samples}

The Roman archeological site of Alburnus Maior, located in the central area of Roşia Montană (Carpeni Hill), has provided a series of exceptional findings over time-gold mine galleries, places of worship, habitat elements, and necropolises [5]. During the archeological campaigns between 2001 and 2003, two buildings with underfloor heating (hypocaustum) were excavated, which most probably functioned as bathhouses (Figure 1a-d). Based on the archeological observations, during the first construction phase, the bathhouse comprised at least three heated rooms, while during the second phase, some space alterations and changes in the functionality of some of the rooms were documented. Several wall painting fragments surviving in situ were found (Figure 1e,f) in what may have been a small compartment near the frigidarium, where a cold-water pool might have functioned [5]. Ceramic brick materials marked with the stamp of the Legio XIII Gemina, together with a series of monetary discoveries in one of the bath rooms, indicate that the bathing facility was most probably built between 117 and 138 (the first years after the establishment of the province of Dacia) $[5,21]$.
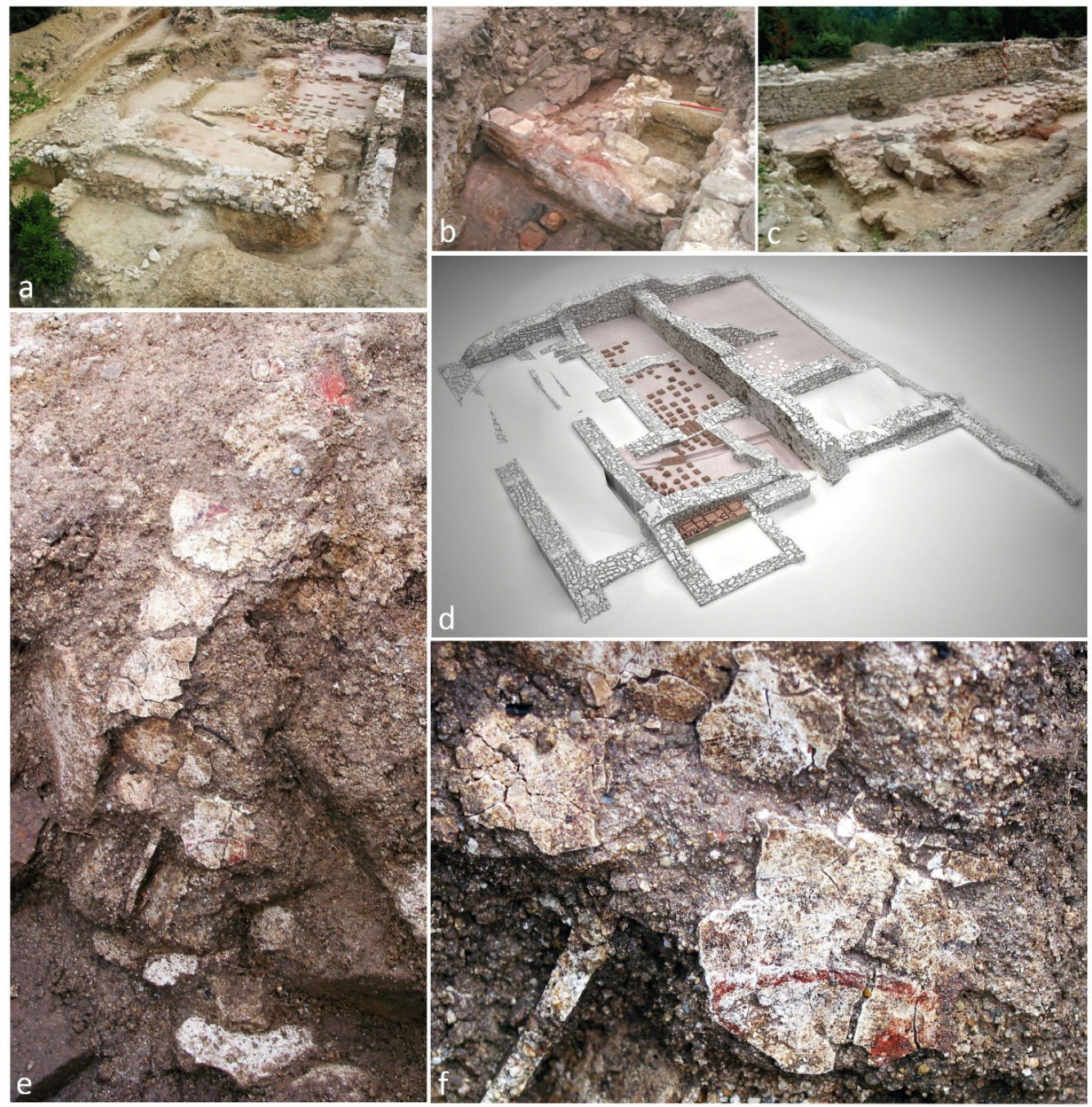

Figure 1. Details showing the ruins of the bathhouse discovered at Alburnus Maior (a-c); 3D model of the bathhouse (d); wall painting fragments found in situ $(\mathbf{e}, \mathbf{f})$. Images reprinted with permission from [5].

The wall painting fragments collected during the excavation of the site are shown in Figure 2. The fragments, very fragile, are characterized by large areas of lost polychromy. 
The preserved painting layers cover a narrow chromatic range-red, yellow, white, and black. Due to the advanced state of degradation, no assumptions can be made regarding decorative patterns, stylistic elements, or painting technique. Several representative samples were selected for investigation. Except for FTIR analysis, all analytical measurements were performed directly on the pigmented areas of the wall painting fragments, without sampling. The plaster layers were also examined.

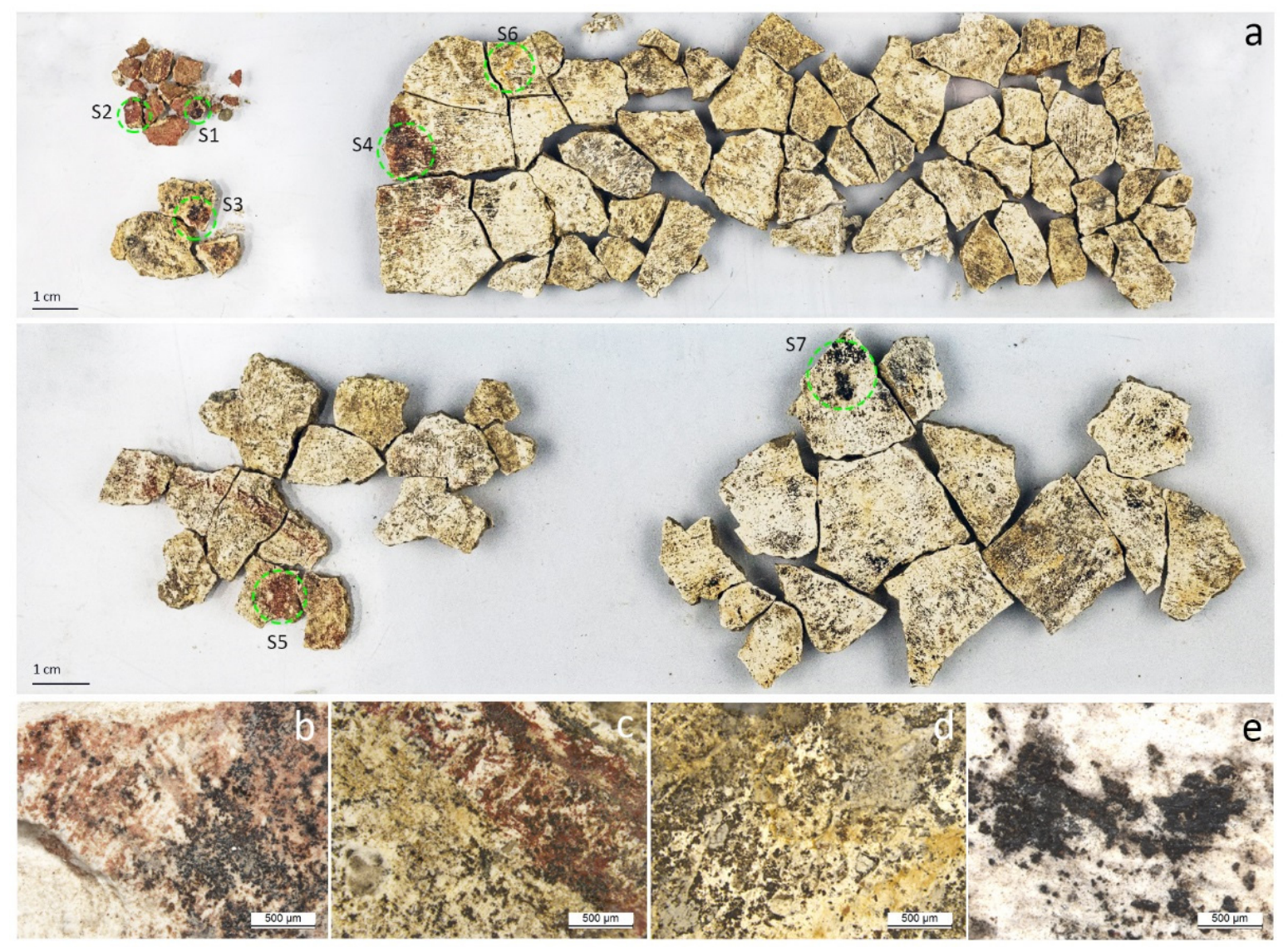

Figure 2. Wall painting fragments discovered at Alburnus Maior (analyzed spots are indicated in the figure) (a); microscopic details of some of the investigated pigmented areas: red mixed with black, sample S4 (b); red mixed with yellow, sample S5 (c); yellow, sample S6 (d); and black, sample S7 (e).

\subsection{Fourier Transform Infrared Spectroscopy (FTIR)}

FTIR analysis was carried out on powder samples in attenuated total reflection (ATR) mode, using a SpectrumTwo FTIR spectrometer (PerkinElmer, Waltham, MA, USA) equipped with a GladiATR accessory (monolithic diamond ATR crystal from Pike Technologies). Small amounts of samples were taken from each colored area by gently scrapping the surface. Spectra were collected in the $4000-380 \mathrm{~cm}^{-1}$ mid-infrared spectral region at $4 \mathrm{~cm}^{-1}$ resolution. A total of 64 scans were used for the optimal signal-to-noise ratio. Data processing was carried out in Essential FTIR Spectroscopy Software Toolbox (Operant LLC, Monona, WI, USA).

\subsection{X-ray Fluorescence (XRF)}

XRF measurements were performed with a portable energy-dispersive instrument from Bruker-TRACER III-SD, provided with a Rh anode X-ray tube and a $10 \mathrm{~mm}^{2} \mathrm{X}$ Flash Silicon Drift Detector (SDD), with an energy resolution of approximately $145 \mathrm{eV}$ at 200,000 cps. For this study, the working parameters were set at $10.60 \mu \mathrm{A}$ current intensity, $40 \mathrm{kV}$ tube voltage, no filtering, air atmosphere, and $60 \mathrm{~s}$ analysis time. Instrument accuracy 
was checked prior to measurements using a stainless-steel duplex 2205 check sample. The nose of the analyzer was cleaned after each sample measurement in order to avoid sample cross-contamination. The instrument's detection limit varies for each element as a function of the physics of the sample, down to ppm level. Elements' identification was conducted in ARTAX software, using standard Bayesian deconvolution. Due to the fact that the experiments were performed in a non-destructive manner, the XRF data are qualitative (semi-quantitative). Data processing and plotting were carried out in Excel 2016.

\subsection{X-ray Diffraction (XRD)}

X-ray diffraction was performed on a SmartLab X-ray diffractometer (Rigaku, Tokyo, Japan) equipped with a $9 \mathrm{~kW} \mathrm{Cu}$ rotating anode and a 5-axis vertical goniometer. The diffractometer was operated in parallel beam mode with high-resolution optics on the incident beam (2-bounce Ge(220) monochromator) to select $\mathrm{Cu}$-Ka1 radiation $(\lambda=1.540597 \AA)$. Pigmented areas were investigated using GIXRD (grazing incidence X-ray diffraction) analysis (incidence angle set at $3^{\circ}$ ), while the mineralogical composition of the wall painting plasters was carried out on mechanically ground samples. All measurements were performed in the range of $10^{\circ}$ to $70^{\circ} 2 \theta$, with a speed of $3^{\circ} / \mathrm{min}$. Peak identification was conducted using the PDXL software database.

\subsection{Imaging Diagnostic Techniques}

A macro-imaging diagnostic analysis was performed in the visible, UV, and IR ranges. Images in raking light were registered using a Nikon Coolpix P900 digital camera and a system of halogen lamps that were positioned at a very narrow angle with respect to the investigated samples. Surface examination under UV fluorescence was achieved with the help of a portable UV lamp from Karl Deutsch, with a maximum peak at $365 \mathrm{~nm}$ and $60 \mathrm{~W} / \mathrm{m}^{2}$ intensity at $400 \mathrm{~mm}$ distance. Images were acquired in dark ambient conditions, without visible radiation.

For short-wave infrared (SWIR) hyperspectral imaging, a HySpex SWIR-384 mobile system from Norsk Elektro Optikk AS was used. The system, equipped with a state-ofthe-art mercury cadmium telluride (MCT) detector, operates between 950 and $2500 \mathrm{~nm}$, covering parts of the NIR and SWIR spectra, and it is available in 288 spectral bands. Samples were evenly illuminated using an optimal wavelength lamp system, and scanning was performed using the push broom method, through the controlled sliding of the camera along an automated translation rail. For the best available resolution, a $30 \mathrm{~cm}$ lens was used. Data processing was performed in the ENVI software package (Harris Geospatial Solutions).

\section{Results}

\subsection{FTIR Analysis}

FTIR spectra registered on all pigmented layers are dominated by the strong absorption bands of calcite $\left(\mathrm{CaCO}_{3}\right)$ - characteristic IR absorptions associated with the fundamental vibrations of the carbonate group observed around $\sim 1400 \mathrm{~cm}^{-1}$ (broad peak), $872 \mathrm{~cm}^{-1}$, and $712 \mathrm{~cm}^{-1}$ [22]. The small peaks at 2512 and $1795 \mathrm{~cm}^{-1}$ (combination bands) can also be ascribed to calcite [23]. As indicated by the FTIR data registered on the white painted areas, calcite was also the choice for the white pigment. In some of the registered FTIR spectra (Figure 3a), the presence of an organic material could be clearly inferred via the weak but characteristic bands observed at 2923 and $2854 \mathrm{~cm}^{-1}$ (aliphatic C-H stretching). For the same samples, the amide I and amide II bands at 1639 and $1588 \mathrm{~cm}^{-1}$ were also observed, a clear indicator of proteins [24]. 

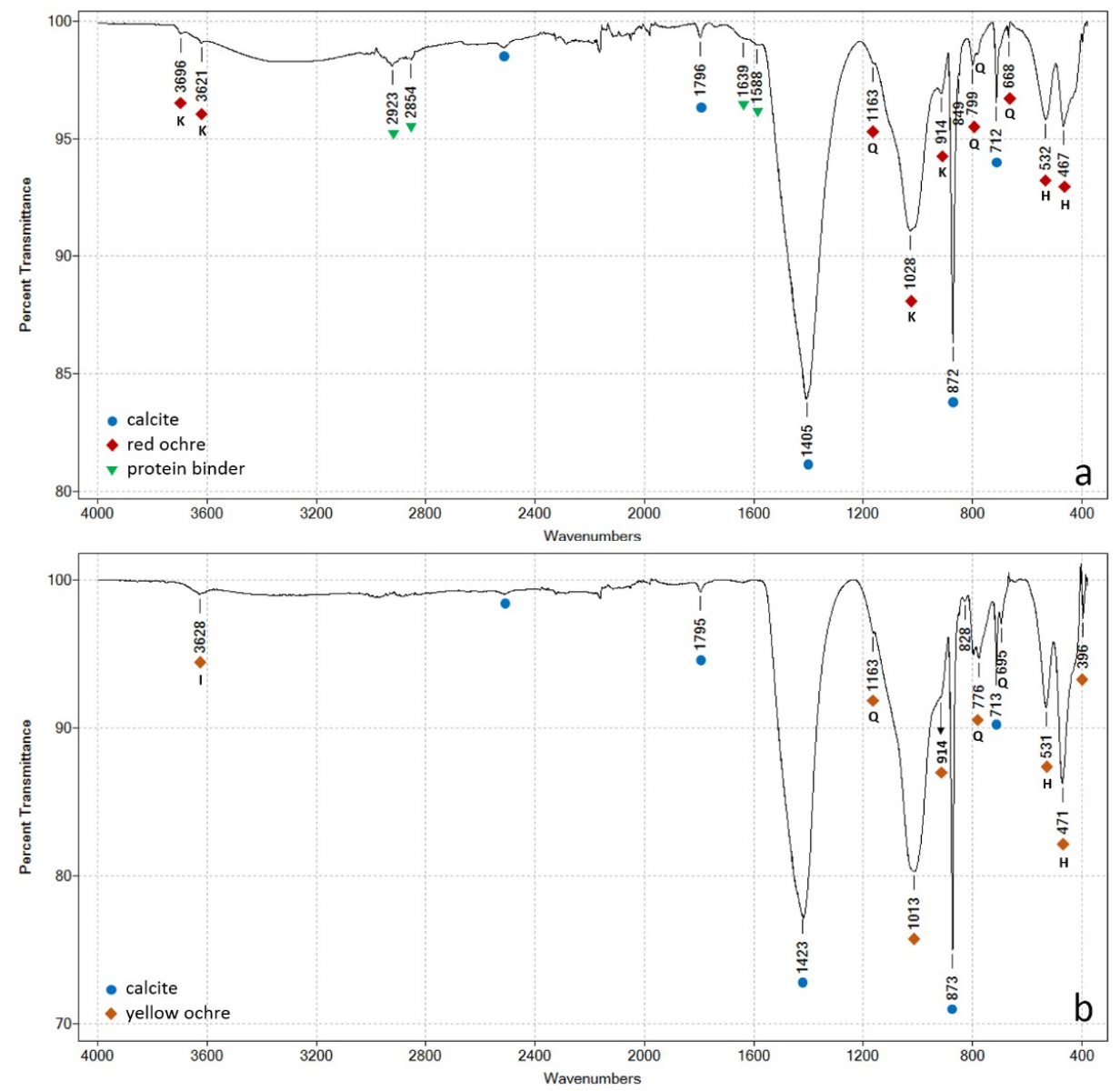

Figure 3. FTIR spectrum registered on the red (a) and yellow (b) pigmented areas (samples S2 and S6). The absorptions of the various accessory minerals associated with the natural ochre pigments are marked on the spectra as follows: $\mathrm{K}$-kaolinite; Q- quartz; $\mathrm{H}$-hematite; I-illite.

Examination of red areas indicated the use of red ochre. As it can be seen in Figure 3a, iron oxides under the form of hematite $\left(\mathrm{Fe}_{2} \mathrm{O}_{3}\right)$ were identified via the specific absorption bands at 467 and $532 \mathrm{~cm}^{-1}$. Compared to the literature [25], this last peak, typically around $550 \mathrm{~cm}^{-1}$, is slightly shifted toward lower wavenumbers, a situation that may be explained by an increase in Al-for-Fe substitution in the hematite structure [26]. The shift towards lower wavenumbers of the hematite IR band could also be due to the particle size and shape (morphology) [27]. Accessory minerals associated with the iron oxide compounds were also identified, such as kaolinite-characteristic bands observed at 3696 and $3621 \mathrm{~cm}^{-1}$ (outer and inner hydroxyl ion bands), $1028 \mathrm{~cm}^{-1}$ (Si-O-Si band), and $914 \mathrm{~cm}^{-1}$ (Al-O-H band). Small amounts of quartz, typically found with kaolinite, were also observed-peaks at 1163,799 , and $781 \mathrm{~cm}^{-1}[25,28]$.

The infrared spectrum registered on the yellow finishing layer (Figure 3b) was found to be somehow similar to the one registered on red areas. However, compared to red ochre, the characteristic peaks of ferric oxides are sharper and more intense. A peak at $397 \mathrm{~cm}^{-1}$, frequently found in ochre or earth-based pigments [29], can also be observed. This band is thought to be due to $\mathrm{SiO}_{4}-\mathrm{SiO}_{4}$ coupling in silicate [30], while other studies assign this band to $\mathrm{Fe}-\mathrm{O}$ bands in yellow ochre [31]. However, no other characteristic bands of either goethite or limonite, commonly found in yellow-based ochres, were observed. Compared to the red pigmented areas, higher amounts of quartz seem to be present, while bands caused by the free hydroxyl ions of kaolinite, in the upper region of the spectra, are missing. Instead, within this region of the spectra, a small peak centered around $3627 \mathrm{~cm}^{-1}$ is present that may be ascribed to Al-OH vibrations in illites [32]. The broad and intense peak at $1013 \mathrm{~cm}^{-1}$, with a shoulder band at $914 \mathrm{~cm}^{-1}$, could be ascribed to kaolinite. This shift 
towards lower wavenumbers of the main vibration in kaolinite (normal values are between 1028 and $1036 \mathrm{~cm}^{-1}$ ) could be due to interferences with the $1085 \mathrm{~cm}^{-1}$ band in quartz as well as the particle size [33]. However, due to the fact that the most characteristic bands for kaolinite in the upper region of the spectra are missing, kaolinite is either not present or present in very small amounts. Based on IR absorptions within the $1270-880 \mathrm{~cm}^{-1}$ region, a clear identification of the clay minerals present in the analyzed sample is not possible by FTIR analysis alone [34]. As shown in previous studies [35], FTIR spectra of clay minerals are complex, where both the position and the intensity of the IR peaks are dependent on the conditions of mineral formations and the presence of various impurity ions and elements within the lattice.

The FTIR profile registered on the black pigment (Figure 4a) is clearly dominated by the absorption bands of calcite. Neither iron oxides nor quartz were found. Instead, manganese oxides may be present, as indicated by the IR bands centered around 1031, 490 (shoulder), and $423 \mathrm{~cm}^{-1}[28,36]$. The small peak at $1627 \mathrm{~cm}^{-1}$ along the broad absorption between 3600 and $3200 \mathrm{~cm}^{-1}$, corresponding to stretching and bending vibrations of water molecules, infers the presence of hydrous Mn oxide. A manganese-rich ochre (black earth) may have been used for the black pigmented layer. As indicated by the existing literature, manganese ochres (also called wads) are composed of complex associations of manganese oxides and hydroxide minerals, and, in certain cases, also iron oxides $[37,38]$ (the presence of iron oxides, although not observed within the FTIR spectra, can be inferred via XRF analysis; see Section 3.2).
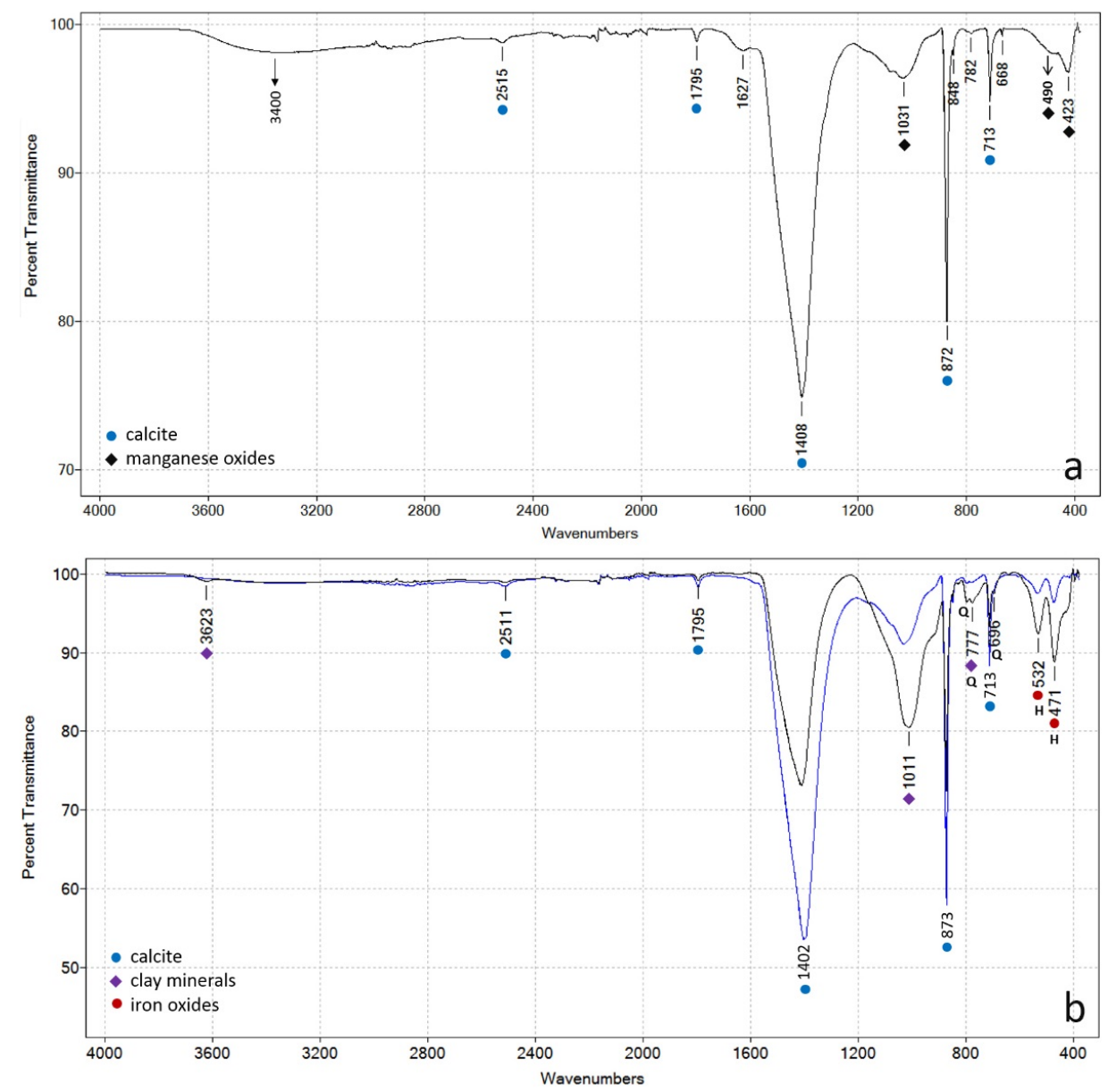

Figure 4. FTIR spectrum registered on the black finishing layer (sample S7) (a) and on the plaster layers (b) (coarse plaster layer with black line; fine plaster layer with blue line). The absorptions of the various mineral components identified are marked on the spectra as follows: Q- quartz; $\mathrm{H}$-hematite. 
Investigation of the coarse plaster layer (arriccio) indicated a similar composition to the one registered for the yellow ochre samples. Strong absorption bands ascribed to calcite were observed $\left(1411,871,713 \mathrm{~cm}^{-1}\right)$, as well as strong peaks assigned to hematite (Figure $4 \mathrm{~b}$ ). Silicates, namely, quartz, were also identified. Some clay minerals are also present, as inferred via the peaks at 3623 and $1011 \mathrm{~cm}^{-1}$. FTIR spectra registered on the fine plaster layer (intonaco) highlighted the presence of calcite with very small amounts of mineral impurities such as iron oxides and possible traces of clay minerals.

\subsection{XRF Analysis}

In order to obtain qualitative information on the chemical composition of the investigated samples, XRF measurements were carried out on various painted areas of the fragments, as well as on the wall painting plasters. The results of the XRF analysis are summarized in Table 1. As expected, and in accordance with the FTIR data, all areas investigated show intense Ca lines (Figure 5), most probably associated with calcite. In order to avoid the layering effect, all samples were measured on the decorated surfaces and also on the back. Taking into account the measurement setup and the penetration depth of the primary X-rays, the calcium contribution partially comes from the pigmented layer, and partially from the plaster used as a substrate. Trace amounts of $\mathrm{Sr}$ were also found in all the investigated areas, most probably due to the substitution of Ca by Sr in the calcite crystal structure [39].

Table 1. Results of the XRF analysis. Identified elements are shown in order of decreasing abundance (major abundant elements are marked in bold; trace elements are marked in italics).

\begin{tabular}{|c|c|c|c|}
\hline Sample & Typology & Color/Typology & Detected Elements \\
\hline S1 & paint layer & red with black & $\begin{array}{c}\text { Fe, Ca, Mn, } \mathrm{Cu}, \mathrm{Ti}, \mathrm{Pb}, \mathrm{K}, \mathrm{Hg}, \mathrm{Zn}, \mathrm{S} \\
\mathrm{Sr}, \mathrm{Si}, \mathrm{P}\end{array}$ \\
\hline S2 & paint layer & red & $\begin{array}{c}\text { Ca, } \mathrm{Fe}, \mathrm{Mn}, \mathrm{Cu}, \mathrm{Ti}, \mathrm{K}, \mathrm{Pb}, \mathrm{S}, \mathrm{Si}, \mathrm{Zn} \\
\mathrm{Hg}, \mathrm{Sr}\end{array}$ \\
\hline S3 & paint layer & yellow, red, and black & $\begin{array}{c}\mathrm{Ca}, \mathrm{Fe}, \mathrm{Mn}, \mathrm{Sr}, K, \mathrm{Cu}, \mathrm{Pb}, \mathrm{Ti}, \mathrm{Zn}, \mathrm{Si}, \mathrm{S}, \\
\mathrm{Rb}, \mathrm{Cr}, \mathrm{Al}\end{array}$ \\
\hline S4 & paint layer & red with black & $\begin{array}{c}\mathrm{Ca}, \mathbf{F e}, \mathrm{Mn}, \mathrm{Sr}, \mathrm{K}, \mathrm{Ti}, A s, \mathrm{Zn}, \mathrm{Pb}, \mathrm{Cu} \\
\mathrm{Si}, \mathrm{R} b, \mathrm{~S}, P\end{array}$ \\
\hline S5 & paint layer & red with yellow & $\begin{array}{c}\mathrm{Ca}, \mathbf{F e}, \mathrm{Mn}, \mathrm{K}, \mathrm{Sr}, \mathrm{Ti}, \mathrm{Pb}, \mathrm{Cu}, \mathrm{Zn}, \mathrm{Si} \\
\mathrm{Cr}, \mathrm{Rb}, \mathrm{S}, \mathrm{P}\end{array}$ \\
\hline S6 & paint layer & white with yellow & $\begin{array}{c}\text { Ca, Fe, Mn, } \mathrm{Sr}, P b, C u, T i, B a, Z n, S, \\
\text { Si, Rb, } P, A l\end{array}$ \\
\hline S7 & paint layer & black & $\mathrm{Ca}, \mathrm{Mn}, \mathbf{F e}, \mathrm{Cu}, \mathrm{Ti}, \mathrm{Pb}, \mathrm{Si}, \mathrm{S}, \mathrm{Sr}, \mathrm{Zn}$ \\
\hline S8 & fine plaster layer & white & $\mathrm{Ca}, \mathrm{Fe}, \mathrm{Sr}, \mathrm{Mn}, \mathrm{Cu}, \mathrm{Ti}$ \\
\hline S9 & coarse plaster & greyish-white & $\mathrm{Ca}, \mathbf{F e}, \mathrm{K}, \mathrm{Mn}, \mathrm{Rb}, \mathrm{Ti}, A s, \mathrm{Sr}, \mathrm{Cu}, \mathrm{Si}$ \\
\hline
\end{tabular}

In terms of key elements that can be associated with the used pigments, all pigmented areas show high amounts of $\mathrm{Fe}$, and for some of the areas, also of $\mathrm{Mn}$, which indicate the presence of iron and manganese-rich ochres [37]. Copper and other various trace elements such as $\mathrm{Ti}, \mathrm{As}, \mathrm{Hg}, \mathrm{Cr}$, and $\mathrm{Zn}$ can be linked with impurities present in the ores used for the manufacturing of pigments [40]. However, the chemical fingerprint of the pigments may have been affected by the burial environment as well. As shown in other studies [41], prolonged burial can lead to different enrichments of leached metals of the soil that determine a change within the original elemental composition of the pigment. $\mathrm{Si}$, which was also found, can be linked with the presence of some common silicates, namely, quartz, as confirmed by FTIR, that accompany the bulk pigment. 


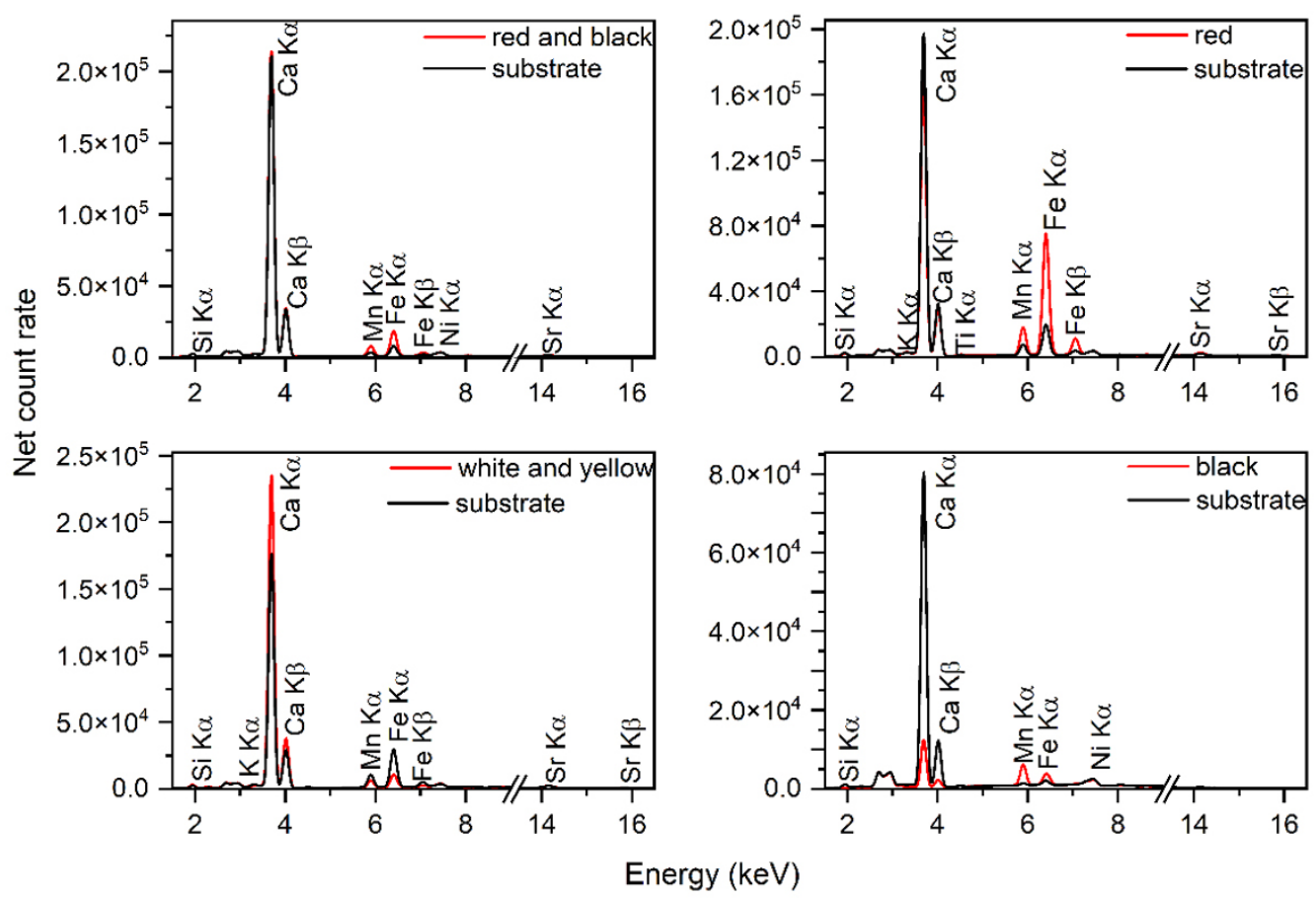

Figure 5. XRF spectra of representative samples (S1-red and black; S2—red; S3—white and yellow; S7-black).

An aspect that stands out from the XRF data is that, compared to all other samples, sample S7 (black pigment) is characterized by an inversed Mn/Fe ratio: while the general tendency was for more iron as compared to manganese, for the black pigment sample, it appears to be exactly the opposite, as illustrated in Figure 6. This would suggest the use of a manganese-containing black pigment, possibly a manganese (di)oxide, which can be found in black ochres [42]. On the contrary, similar samples analyzed from the site of Ulpia Traiana Sarmizegetusa all had more iron as compared to manganese [6].

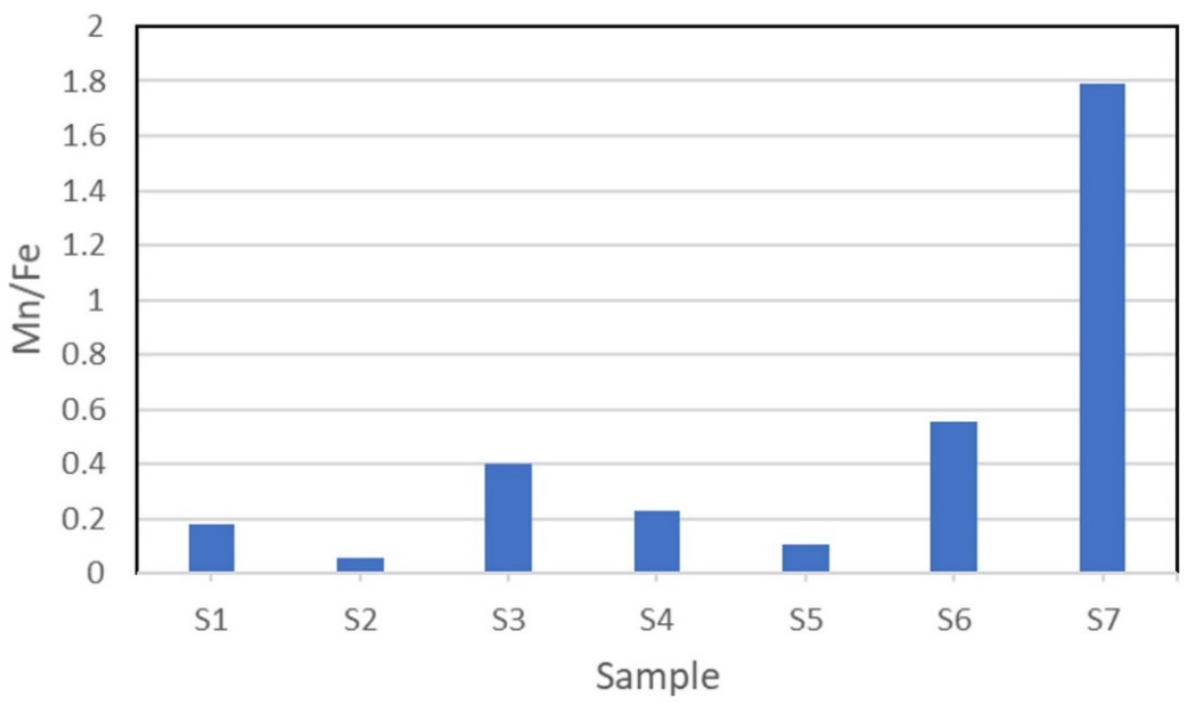

Figure 6. Manganese versus iron ratio for all pigment samples.

For each sample, the substrate was also analyzed (Figure 5), indicating Ca as a major component, along with a smaller input of Fe and Mn, which can be associated with calcite impurities, as it is known that $\mathrm{Mn}^{2+}$ ions can substitute for $\mathrm{Ca}^{2+}$ ions in marbles [43]. Additionally, minor traces of terrigenous materials were evidenced, such as $\mathrm{K}$, $\mathrm{S}$, and Ti. 
Compared to the decorated layers, the XRF data registered on the coarse plaster indicate higher-intensity lines for $\mathrm{K}$ that could be linked to common potassium feldspars or micas. Rubidium, a trace element frequently embedded within the lattices of numerous potassiumcontaining minerals, was also found [44].

\subsection{XRD Analysis}

The XRD patterns registered on the pigmented layers were all very similar, with several mineral phases being observed on all investigated fragments: calcite, quartz, and hematite. As shown in Figure 7, calcite is the main phase identified. The high intensity of the calcite peaks within the recorded diffractograms indicates that the pictorial layer is not thick enough to mask the strong signal coming from the substrate [45].
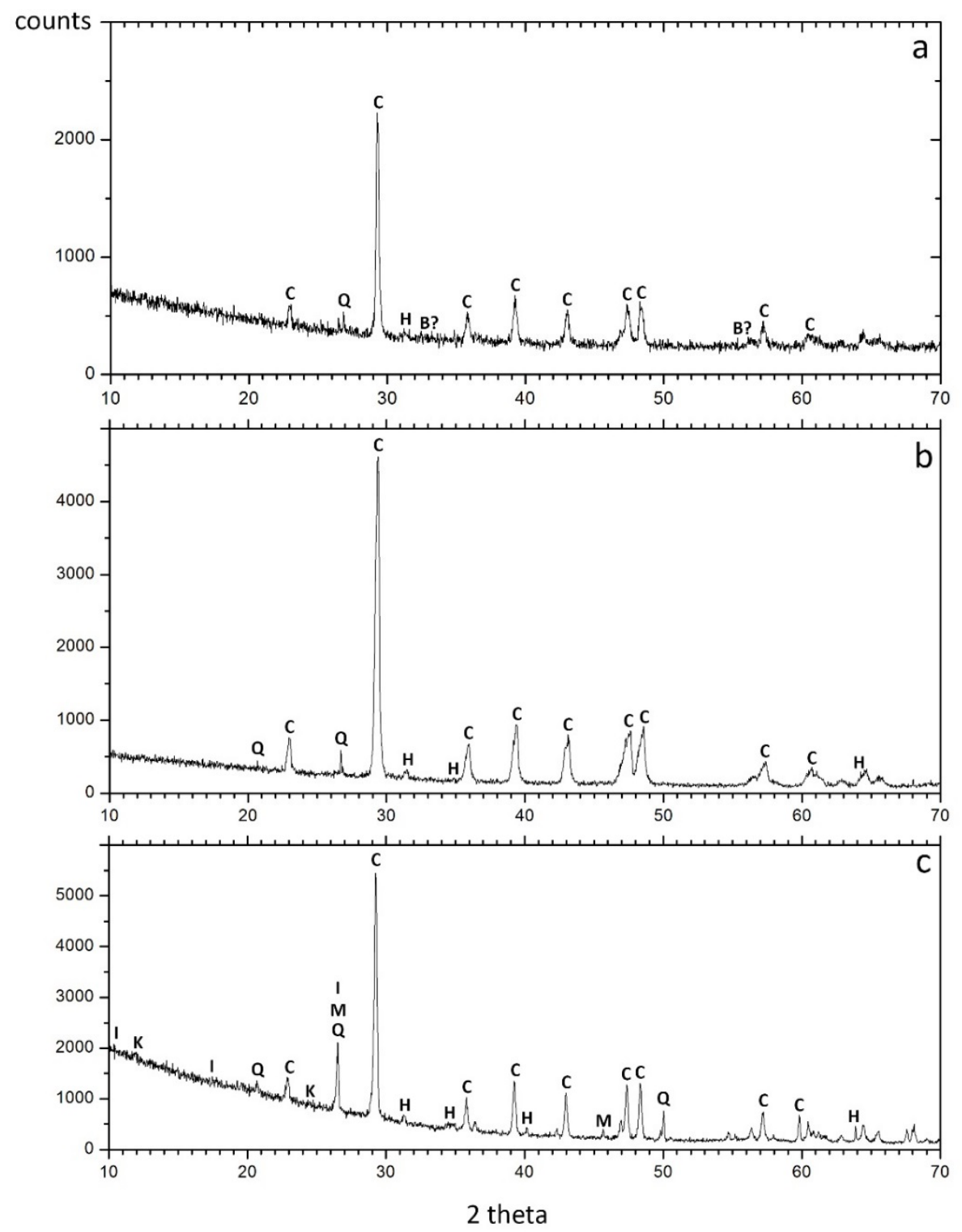

Figure 7. XRD pattern registered on the black pigmented area (sample S7) (a), on the yellow pigmented area (sample S6) (b), and on the coarse plaster layer (sample S9) (c). Identified mineral phases are marked as follows: $\mathrm{C}$-calcite; $\mathrm{Q}-$ quartz; $\mathrm{H}$-hematite; $\mathrm{K}$-kaolinite; $\mathrm{M}-$ muscovite; I-illite; B-braunite.

Braunite $\left(\mathrm{Mn}_{2} \mathrm{O}_{3}\right)$, a naturally occurring manganese oxide frequently found in metamorphic manganese-rich systems and in hydrothermal deposits, could be present in the 
black finishing layer (Figure 7a) [46]. The presence of a manganese oxide is sustained by both FTIR and XRF data. As indicated in previous studies [37,38], wads (manganese ochres) are typically composed of one or more manganese oxide minerals along with other associated ore and gangue minerals such as quartz, feldspar, calcite, or iron oxides. Quartz and iron oxides under the form of hematite were observed in all pigmented areas, including the black finishing layer, indicating that both quartz and hematite grains are associated with the manganese oxide pigment in this latter case [45].

The presence of goethite, typically found within yellow-based ochres [37], could not be highlighted within the X-ray diffraction pattern (Figure 7b). Limonite, jarosite ochres, or less common yellow iron oxides such as hydroxide lepidocrocite $(\Upsilon$-FeOOH) were also ruled out. This situation could be due to the low concentration of the iron oxide chromophore present within the investigated yellow pigmented layers. However, small amounts of hematite could be observed, which may indicate that the yellow color of the used pigment could be due to a mix of hematite (and most probably goethite as well) with clay minerals and other metal oxides [28].

The results of the X-ray powder analysis carried out on the coarse plaster layer indicate that calcite and quartz are the main mineralogical components (Figure 7c). Small amounts of kaolinite, muscovite, illite, and hematite were also confirmed. The presence of muscovite can be correlated with the rich potassium content, a indicated by XRF analysis. All other components were also identified via FTIR analysis.

\subsection{Imaging Documentation}

Examination of the wall painting fragments under raking light (Figure 8a) highlighted specific details that indicate that the wall paintings may have been created using the $a$ secco technique. No characteristic technical hallmarks of a fresco painting are present: no evidence of the typical shiny surface given by the carbonatation crust, no technological incisions made on the fresh plaster (to help in the process of drawing), and, most importantly, no traces of smoothing or polishing of the surface made by trowel blades [24,47]. This hypothesis is sustained by the registered FTIR data that indicate, for some of the investigated samples, the presence of an organic binder. The use of the $a$ secco technique would also explain the conservation state of the pictorial layers-mainly very fragile, with poor adhesion to the support, a consequence of the natural deterioration of the organic binder.
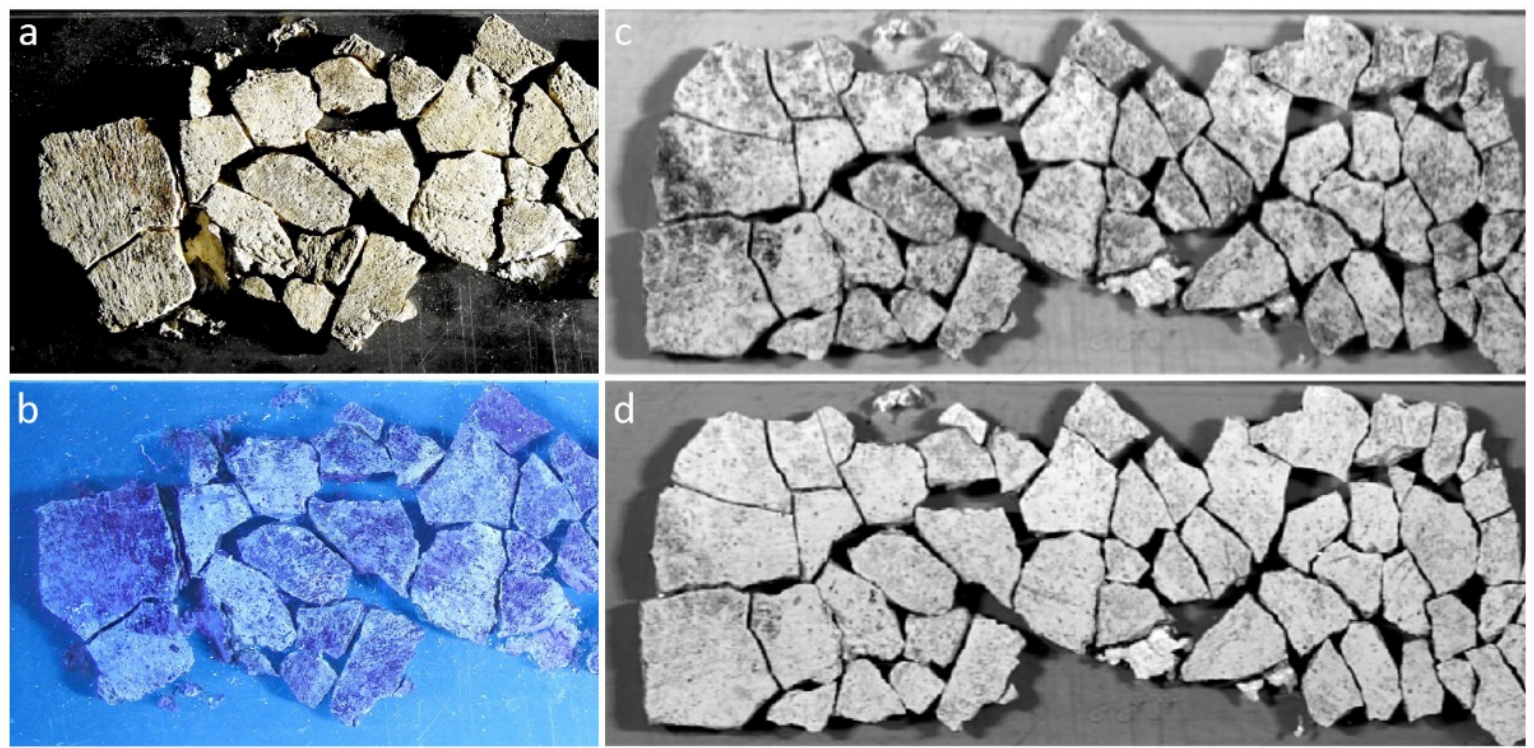

Figure 8. Details in raking light (a) and under UV fluorescence examination (b). Hyperspectral imaging details that highlight the behavior of the pigments at specific wavelength values: $954 \mathrm{~nm}(\mathbf{c}) ; 1600 \mathrm{~nm}(\mathrm{~d})$. 
Images registered at different wavelengths of the SWIR region (Figure 8c,d) suggest that a carbonaceous material may have been used for the black pigmented areas, most probably carbon black. This hypothesis is based on the fact that some of the pigmented areas are visible in infrared light (these areas correspond to a pigmented layer based on a mixture of red and black pigments). Carbon-based blacks were frequently used by the Romans, alone or admixed with other pigments in order to obtain different shades, such as brown (obtained from hematite darkened red with amorphous carbon) [48,49].

Given the large areas of lost polychromy as well as the poor visible trace of some of the pigments (mainly the yellow ochre pigments), the SWIR hyperspectral data cubes were processed using linear spectral unmixing (LSU) with the aim to enhance the presence of the pigments used for the surface decoration of the wall painting fragments. The LSU algorithm was applied since it is able to generate abundance maps of pixels with a specific spectral profile. These are constructed by identifying the endmembers and the fractional abundances that correspond to each pixel. Moreover, LSU calculation allows classifying areas with mixed pixels based on their statistic values [50,51]. The main endmembers (corresponding to the various pigmented areas) were selected using the regions of interest (ROI). The results of the applied algorithm are displayed as abundance maps (Figure 9), with bright pixels representing higher abundance. The classification algorithm returned unsatisfactory results - the actual distribution of the red pigment, for example, did not perfectly match with the resulting fraction (Figure 9b).

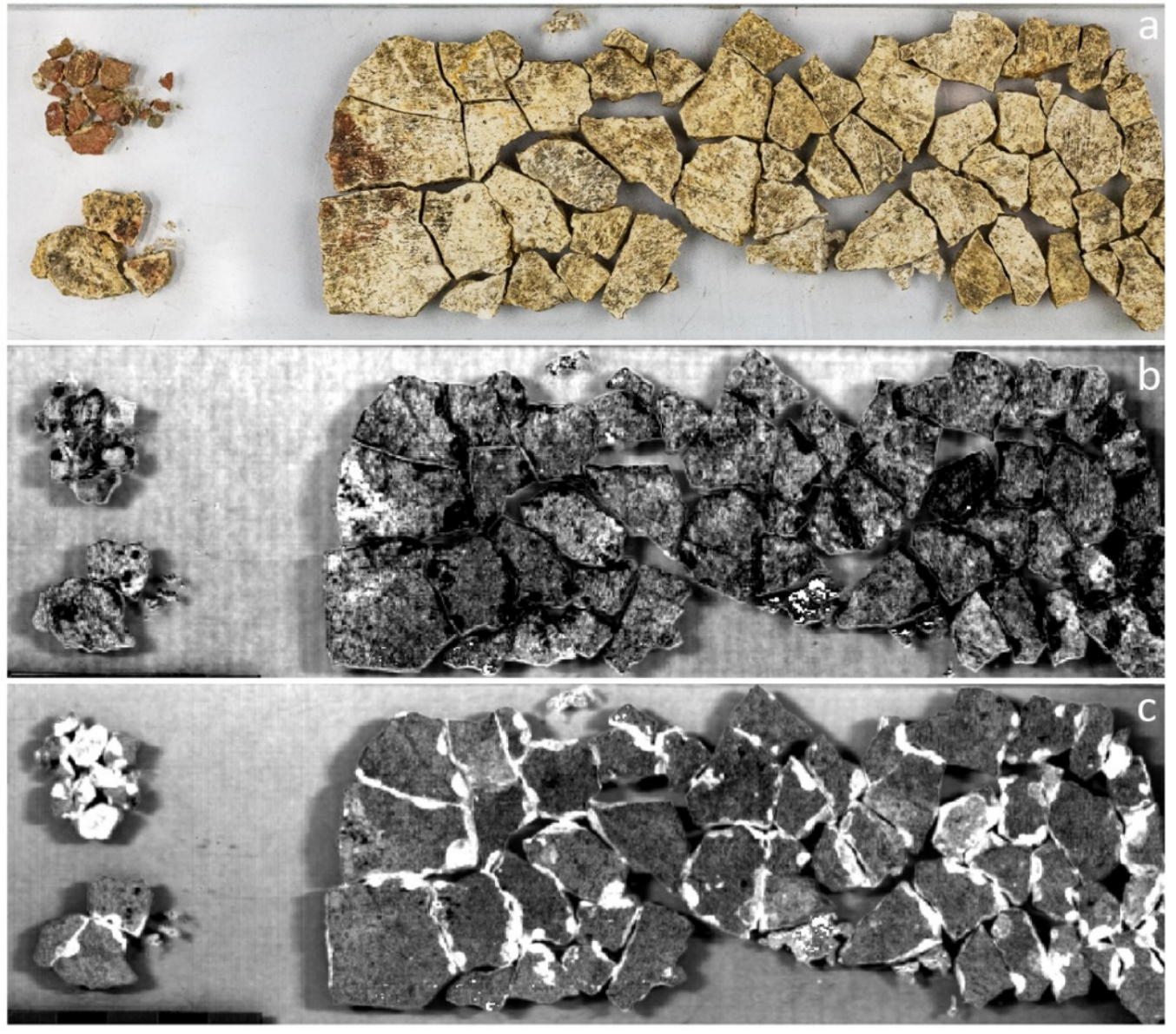

Figure 9. Results of the LSU classification obtained on a selection of samples. Visible color image (a); abundance map of the red ochre pigment (b); abundance map of the identified adhesive (c). Bright pixels represent higher abundance.

Further analysis indicated that the results of the LSU classification were affected by the presence of a synthetic adhesive used by the archaeologists to fix the wall painting 
fragments on a Plexiglas support immediately after excavation. As it can be seen in Figure $9 c$, this adhesive partially contaminated the surface of the wall painting fragments, including some of the pigmented areas. In the hyperspectral data cube, the spectral response of the adhesive could be slightly traced in the interval between 2454 and 2204 $\mathrm{nm}$ (characteristic infrared band for synthetic resins were also observed in some of the investigated samples under FTIR analysis; these samples were considered contaminated and excluded from the study). The presence of this organic consolidant also explains the high absorption in the UV region registered for some of the areas (Figure $8 b$ ). The unambiguous presence of calcium carbonate in all areas, highlighted by the presence of absorption between 2100 and $2400 \mathrm{~nm}$ [52], may also have influenced the LSU classification.

\section{Discussion}

The structure of the wall painting fragments discovered in the Roman baths from Alburnus Maior showed a typical three-layer structure: a mortar layer (arriccio), a fine plaster layer (intonaco), and a paint layer [24]. Combined analysis highlighted a very common Roman color palette mainly based on mineral pigments-red ochre (hematite), yellow ochre (a mix of hematite and most probably goethite as well), manganese-rich ochre (possible braunite), and carbon black. All identified pigments fall in the category of colores austeri (plain colors) as defined by Pliny $[9,49]$. Compared to the color palette identified on second century wall paintings from Ulpia Traiana Sarmizegetusa [6], or within the painting hall with hypocausts from Apulum [11], the palette from Alburnus Maior is plainer. No costly pigments (colores floridi) such as minium, cinnabar, azurite, or malachite were found. The use of mainly naturally occurring earth pigments within the baths' decoration from Alburnus Maior suggests that the bathing facility was not intended for the elite (Roman officials) [49]; the historical and archaeological data indicate that the bathhouse operated in an area frequented by administrative staff, soldiers, and civilians [5]. Given the large areas of lost polychromy, an exact assessment of the full range of colors initially employed for the decorations within the Roman baths from Alburnus Maior is not possible. If costly pigments typically restricted to particularly luxurious decorations can be excluded in this case, a wider range of austeri pigments (e.g., green earths, umbers) or pigment mixtures could have been used.

In terms of painting technique, the presence of a protein binder could be clearly identified in some of the samples by FTIR analysis. An organic binder such as egg, glue, or animal fat may have been used [24]. These findings, along with the absence of any technical hallmarks of a fresco painting, are clear indicators that at least some of the pigments were applied with the secco technique [16]. The high concentration of calcium carbonate registered within the pigmented areas most probably indicates that a lime rendering (whitewash) was applied, common for both a fresco and a secco [47]. Previous studies performed on wall painting fragments discovered at Ulpia Traiana Sarmizegetusa [6] indicated the use of a fresco-secco technique, with lime used as a binder. None of the FTIR spectra registered in those studies showed any signal for organic compounds potentially used as binders. However, the accurate identification of binders could have been affected by various factors: degradation of the original compounds, limited number of samples, or small sampling areas [47]. These same limitations could also explain why a protein signal was observed only in some of the investigated samples from Alburnus Maior.

The hypothesis of using a different painting technique at a Roman nearby site from the same period is unlikely. Based on the findings from Alburnus Maior, new wall painting fragments from Ulpia Traiana Sarmizegetusa were investigated in terms of painting technique. Figure 10 presents the imaging documentation of one of the new samples investigated: a wall painting fragment showing red and yellow ochre decorations. UV fluorescence examination highlighted a strong fluorescence of the yellow ochre pigmented areas on the left half of the sample, which, in the visible spectrum, are almost indistinguishable. Based on the fact that iron oxides/ochres lack fluorescence as they absorb UV light, the registered fluorescence is most probably due to the presence of an organic binder [53]. 
The hypothesis that the fragment comes from an a secco painting is also sustained by the texture of the surface. As it can easily be observed in raking light, the surface is rough, meaning that the plaster contained a great proportion of sand, but also that the surface was not polished-an operation which was used not for esthetical reasons, but for technical reasons. In fresco painting, in order to provide a much-needed additional quantity of humidity to the surface, the plaster is deliberately pressed and polished. This operation provides the painter extra time to finish the composition $[9,47]$.
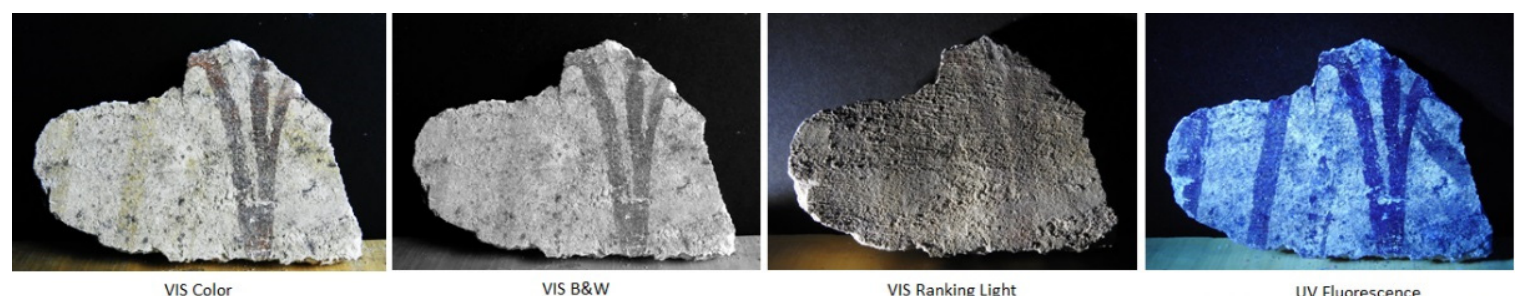

VIS B\&W

VIS Ranking Light
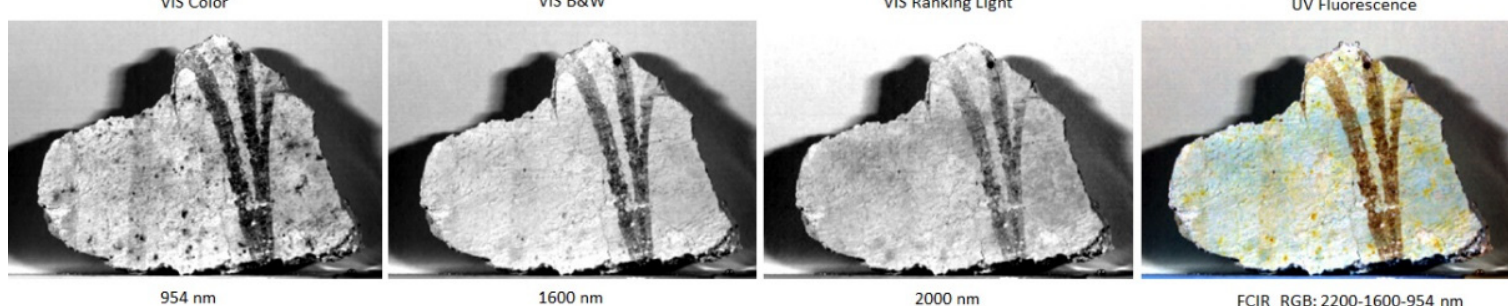

Figure 10. Imaging documentation obtained on a wall painting fragment from Ulpia Traiana Sarmizegetusa.

Based on these results, several samples were collected and analyzed with FTIR spectroscopy. As expected, the registered FTIR spectra were dominated by strong absorptions coming from calcite. However, for some of the investigated pigmented areas, small but very characteristic bands associated with aliphatic $\mathrm{C}-\mathrm{H}$ bands could be observed: peaks at 2925 and $2855 \mathrm{~cm}^{-1}$ (Figure 11). For these same samples, a closer examination within the amide region highlighted some spectral variations: shoulder bands around 1650 and $1584 \mathrm{~cm}^{-1}$ that may indicate the presence of a protein binder. As already discussed in previous studies $[6,24,47]$, several factors may limit the capability of the FTIR technique to accurately identify the presence of organic materials in ancient wall painting samples, such as the low concentration of the binder and the strong absorption of the inorganic matrix (that gives rise to wide bands associated with distortions). In order to accurately assess the presence of an organic binder, refined procedures or more sensitive techniques need to be employed $[16,54,55]$. The use of remote non-invasive techniques capable of investigating larger and targeted areas will also be taken into account in future studies [56,57].

The analysis of the coarse plaster layer (arriccio) of the samples coming from Alburnus Maior highlighted a very heterogeneous composition, mainly based on calcite and siliceous sands (quartz), along with a series of other components such as kaolinite, illite, muscovite, and hematite, with hematite present in relative high concentrations. Unlike the arriccio, the intonaco layer shows no grains of sand or other fine aggregates, and it is characterized by a homogeneous white color and a richer calcium content. For the application of this fine lime-based layer, a process similar to that of traditional whitewashing may have been used. Similar results both in terms of the composition and sequence of layers were registered on the plasters from Ulpia Traiana Sarmizegetusa [6]. As discussed in numerous studies [9,58-60], the number of plaster layers as well as their composition varies according to the historical period and local practice. Depending on the location of the underlayer, the ratio between the binder (slaked lime) and the inert materials varies. The layer that is closest to the stone or brick wall is the thickest and roughest, ensuring good adhesion to the support, while the top layer is thinner and has the finest texture. In practice, regional adaptation and adjustments were frequent, especially in the provinces (the peripheral area of the Roman Empire), where, in general, a lower number of plaster coatings were used [9]. 
In this particular case, the traditional two-plaster layer sequence (arriccio, intonaco) was used, indicating that the workers who produced them had good technological knowledge. The iron-rich content registered for the coarse plaster layer (typically based on river sand and slaked lime [24]) can be considered a local adaptation and indicates the use of clay-rich materials within the matrix.

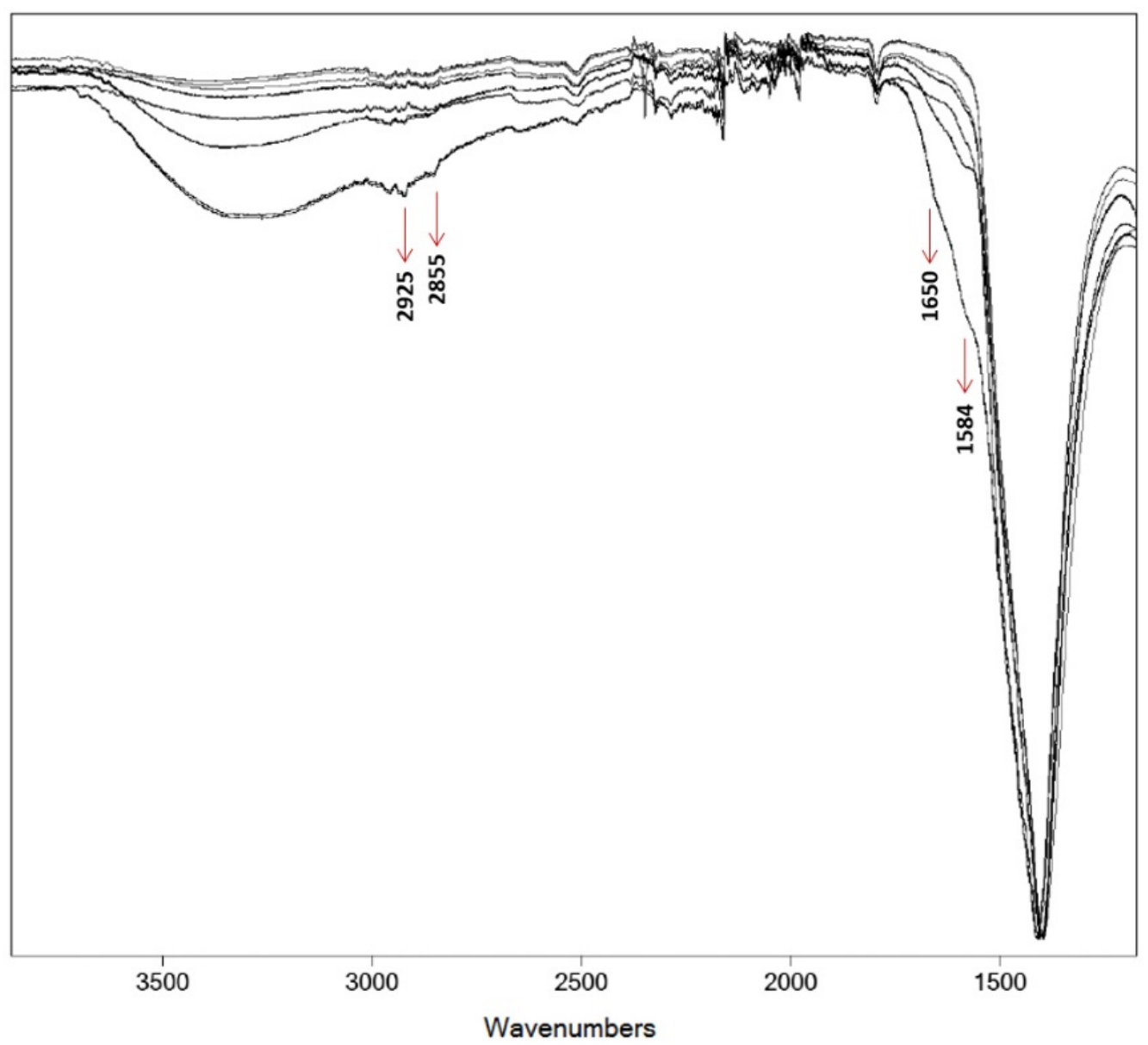

Figure 11. FTIR spectral details showing specific features that infer the presence of an organic binder within the investigated samples from Ulpia Traiana Sarmizegetusa.

As shown in previous studies $[60,61]$, the mineralogical characteristic of the plasters can be related to the geographic location, and it can be used to identify the provenance of the raw materials used. We assumed that most of the construction materials used for the plasters coming from Alburnus Maior were obtained from local sources. Previous studies focused on the mineralogical and geological characterization of several ceramics found at Alburnus Maior which indicated that the provenance area for the raw clayish materials used was within the surroundings of Alba Iulia (Apulum) [62], which is relatively close (less than $80 \mathrm{~km}$ away) to the Alburnus Maior site. These raw clay minerals were found to be polymictic clays, with mica and iron oxihydroxide contents. The same study indicated that the quartz sands used came from the right bank of the Mures River, southeast of Alba Iulia (a location that provides quartz sands to the present day). Given the fact that the ceramic findings and the wall painting fragments investigated in the current study belong to the exact chronological segment [5], it is possible that the same raw material source locations were used in both cases.

Regarding the geological origin of the pigments used, at this moment, only hypotheses can be established. Calcite may have been obtained from local sources of chalk of dolomitic limestone. Ochres, on the other hand, might have been brought by painters from sources outside Dacia. Ancient sources of red ochres included Sinope and the Black Sea, while 
ancient varieties of yellow ochres came from Italy [9]. Geological sources of wads are poorly described in the literature [37]. Based on the registered XRF data, the same geological source might have been used for the red and yellow ochre pigments used at Alburnus Maior and Ulpia Traiana Sarmizegetusa [6], with the chemical fingerprint being very similar in both cases- $\mathrm{Cu}, \mathrm{Ti}, \mathrm{Mn}, \mathrm{As}, \mathrm{Cr}, \mathrm{Hg}$, Zn. If confirmed, this hypothesis would indicate the existence within the Roman province of Dacia of a trade route with centers of pigment extraction and production. The hypothesis that some of the pigments might have been extracted from Roșia Montana (an area of extensive gold mining), or from other sources of hematite closer by, can also be taken into account. A more in-depth analysis is needed to accurately establish the variation in the minor and trace element contents of the ochre pigments that could then be linked to a particular source.

\section{Conclusions}

In this work, an array of non- and micro-invasive techniques was used to examine the materials and painting technique of several wall painting fragments found at the Roman baths from Alburnus Maior (Roșia Montană, Romania). The results of this investigation allowed a qualitative characterization of the chemical and mineralogical composition of the pigments and plasters used as support. The identified color palette included only austeri pigments (common earth pigments) as defined by Pliny: red ochre (hematite) for the red, yellow ochres (hematite probably mixed with goethite) for the yellow, manganese-rich ochres (possibly braunite) mixed with carbon for the black, and calcite for the white. As for the painting method, the FTIR analysis performed pointed to the use of the $a$ secco technique, with characteristic infrared absorptions for a protein binder (egg or animal fat) being observed in some of the investigated samples. The presence of organic binders within the painting layers was also supported by imaging documentation that highlighted various technical details in regard to the working methods. The mortar technology employed included two layers (arriccio and intonaco). The arriccio consisted mainly of lime (calcite) and siliceous sands (quartz) admixed with iron oxides and low amounts of clay minerals, while the intonaco was based almost on pure lime. For the plasters, local sources were most probably used: clay deposits within the surroundings of Alba Iulia, and quartz sands from the right bank of the Mures River.

The obtained results were discussed in light of the archeological context and existing earlier studies carried out on wall painting fragments from the same period. Moreover, new wall painting fragments from Ulpia Traiana Sarmizegetusa (a nearby important Roman archeological site) were analyzed in terms of painting technique. The registered data indicate that the pigments were applied a secco, and not a fresco as initially thought, with the presence of an organic binder being inferred via FTIR analysis as well as combined imaging documentation. Some limitations of FTIR spectroscopy in terms of the capability to accurately identify the presence of organic binders (present in low concentrations) in small wall painting fragments were also discussed.

While, in terms of pigments and manufacturing technique, some similarities were found between the sites of Alburnus Maior and Ulpia Traia Sarmizegetusa, there were also some differences, specifically regarding the pigments used for the black, red, and white areas. The black-colored areas appear to have been made with a mixture of a manganesebased pigment and carbon black in the case of Alburnus Maior, as opposed to the pigment used at Ulpia Traiana Sarmizegetusa, which was found to be bone black. Additionally, no traces of the less encountered white pigment discovered at Ulpia Traiana Sarmizegetusa, strontianite white, were found at the Alburnus Maior site, where the white pigment was calcite. One of the red pigments identified at Ulpia Traian Sarmizegetusa, red lead, does not appear to be present in the samples from Alburnus Maior, where the only red pigment identified was red ochre (hematite). The question of whether these differences between the two closely located archaeological sites are related to the personal choice of the craftsmen or the available (locally or imported) materials needs additional research in order to be properly answered and put into context. 
Overall, the results of this study bring to light new information regarding the materials and pictorial techniques used for the execution of decorative polychrome wall paintings within the Roman provinces. The first evidence regarding the use of the a secco painting technique within two important Roman archeological sites from the Roman province of Dacia is presented. These findings add an important contribution to the existing literature regarding the use of organic binders in Roman wall paintings and testify the high technical skills and esthetic awareness of the Roman artisans.

Author Contributions: Conceptualization, I.M.C. and O.T.; investigation and data analysis, I.M.C., L.R., L.G. and M.D.; writing—original draft preparation, I.M.C., L.R., L.G. and O.T.; writing-review and editing, I.M.C.; funding acquisition, I.M.C. All authors have read and agreed to the published version of the manuscript.

Funding: This research was funded by the Romanian Ministry of Education and Research, CNCSUEFISCDI, grant number PN-III-P1-1.1-PD-2019-1099.

Data Availability Statement: The data that support the findings of this study are available on request from the corresponding author.

Conflicts of Interest: The authors declare that they have no competing interest.

\section{References}

1. Kosso, C.; Scott, A. The Nature and Function of Water, Baths, Bathing and Hygiene from Antiquity through the Renaissance; Brill: Leiden, The Netherlands, 2009.

2. Nielsen, I. Thermae et Balnea: The Architecture and Cultural History of Roman Public Baths; Aarhus University Press: Aarhus, Denmark, 1993.

3. DeLaine, J. Recent research on Roman baths. J. Rom. Archaeol. 1988, 1, 11-32. [CrossRef]

4. Tentea, O.; Burkhardt, B. Bath and bathing in Dacia (1). Current state of research of the balnea. J. Anc. Hist. Archaeol. 2020, 7, 12-21. [CrossRef]

5. Tentea, O. Bath and Bathing at Alburnus Maior; Mega Publishing House: Cluj-Napoca, Romania, 2015.

6. Cortea, I.M.; Ghervase, L.; Tentea, O.; Pârău, A.C.; Rădvan, R. First Analytical Study on Second-Century Wall Paintings from Ulpia Traiana Sarmizegetusa: Insights on the Materials and Painting Technique. Int. J. Archit. Herit. 2020, 14, 751-761. [CrossRef]

7. Piovesan, R.; Siddall, R.; Mazzoli, C.; Nodari, L. The Temple of Venus (Pompeii): A study of the pigments and painting techniques. J. Archaeol. Sci. 2011, 38, 2633-2644. [CrossRef]

8. Coccato, A.; Mazzoleni, P.; Spinola, G.; Barone, G. Two centuries of painted plasters from the Lateran suburban villa (Rome): Investigating supply routes and manufacturing of pigments. J. Cult. Herit. 2021, 48, 171-185. [CrossRef]

9. Ling, R. Roman Painting; Cambridge University Press: New York, NY, USA, 1991.

10. Ciobanu, R. Pictura Murală Romană (La Peinture Murale Romaine); Alba Iulia: Editura Grinta, Romania, 2011.

11. Ciobanu, R. The Paintings Hall with Hypocausts from Apulum II. Apulum 2005, 42, 123-136.

12. T,entea, O.; Olteanu, B.C. Decorating Overlapping Buildings: A Domus and Palmyrene Temple at Colonia Dacica Sarmizegetusa. Theor. Rom. Archaeol. J. 2020, 3, 6. [CrossRef]

13. Boroș, D.; Duca, V. Tencuiala pictată din amfiteatrul de la Porolissum (consideraţii tehnice). AMP 2008, 30, 113-122.

14. Caggiani, M.C.; Coccato, A.; Mazzoleni, P.; D'Alessio, A.; Russo, A.; Barone, G. Integrated analytical approach to unveil the secrets of the recently discovered 'Sphinx Room': A new piece of Domus Aurea puzzle. Herit. Sci. 2020, 8, 124. [CrossRef]

15. Edreira, M.C.; Feliu, M.J.; Fernández-Lorenzo, C.; Martín, C. Roman wall paintings characterization from Cripta del Museo and Alcazaba in Mérida (Spain): Chromatic, energy dispersive X-ray flurescence spectroscopic, X-ray diffraction and Fourier transform infrared spectroscopic analysis. Anal. Chim. Acta 2001, 434, 331-345. [CrossRef]

16. Cerrato, E.J.; Cosano, D.; Esquivel, D.; Jiménez-Sanchidrián, C.; Ruiz, J.R. Spectroscopic analysis of pigments in a wall painting from a high Roman Empire building in Córdoba (Spain) and identification of the application technique. Microchem. J. 2021, 168, 106444. [CrossRef]

17. Angelini, I.; Asscher, Y.; Secco, M.; Parisatto, M.; Artioli, G. The pigments of the frigidarium in the Sarno Baths, Pompeii: Identification, stratigraphy and weathering. J. Cult. Herit. 2019, 40, 309-316. [CrossRef]

18. Asscher, Y.; Angelini, I.; Secco, M.; Parisatto, M.; Chaban, A.; Deiana, R.; Artioli, G. Combining multispectral images with X-ray fluorescence to quantify the distribution of pigments in the frigidarium of the Sarno Baths, Pompeii. J. Cult. Herit. 2019, 40, 317-323. [CrossRef]

19. Fischer, C.; Kakoulli, I. Multispectral and hyperspectral imaging technologies in conservation: Current research and potential applications. Stud. Conserv. 2006, 51, 3-16. [CrossRef]

20. Cucci, C.; Picollo, M.; Chiarantini, L.; Uda, G.; Fiori, L.; De Nigris, B.; Osanna, M. Remote-sensing hyperspectral imaging for applications in archaeological areas: Non-invasive investigations on wall paintings and on mural inscriptions in the Pompeii site. Microchem. J. 2020, 158, 105082. [CrossRef] 
21. Tentea, O.; Burkhardt, B. Baths on the Frontiers of Roman Dacia; Mega Publishing House: Cluj-Napoca, Romania, 2017.

22. Crupi, V.; Allodi, V.; Bottari, C.; D’Amico, F.; Galli, G.; Gessini, A.; La Russa, M.F.; Longo, F.; Majolino, D.; Mariotto, G.; et al. Spectroscopic investigation of Roman decorated plasters by combining FT-IR, micro-Raman and UV-Raman analyses. Vib. Spectrosc. 2016, 83, 78-84. [CrossRef]

23. Miliani, C.; Rosi, F.; Daveri, A.; Brunetti, B.G. Reflection infrared spectroscopy for the non-invasive in situ study of artists' pigments. Appl. Phys. A Mater. Sci. Process. 2012, 106, 295-307. [CrossRef]

24. Pique, F.; Verri, G. Organic Materials in Wall Paintings (Project Report); The Getty Conservation Institute: Los Angeles, CA, USA, 2015.

25. Bikiaris, D.; Daniilia, S.; Sotiropoulou, S.; Katsimbiri, O.; Pavlidou, E.; Moutsatsou, A.P.; Chryssoulakis, Y. Ochre-differentiation through micro-Raman and micro-FTIR spectroscopies: Application on wall paintings at Meteora and Mount Athos, Greece. Spectrochim. Acta-Part A Mol. Biomol. Spectrosc. 2000, 56, 3-18. [CrossRef]

26. Salama, W.; El Aref, M.; Gaupp, R. Spectroscopic characterization of iron ores formed in different geological environments using FTIR, XPS, Mössbauer spectroscopy and thermoanalyses. Spectrochim. Acta-Part A Mol. Biomol. Spectrosc. 2015, 136, 1816-1826. [CrossRef] [PubMed]

27. Helwig, K. The characterisation of iron earth pigments using infrared spectroscopy. In Proceedings of the Second Infrared and Raman User's Group (IRUG 2) Conference, Victoria and Albert Museum, London, UK, 12-13 September 1995; pp. 83-92.

28. Genestar, C.; Pons, C. Earth pigments in painting: Characterisation and differentiation by means of FTIR spectroscopy and SEM-EDS microanalysis. Anal. Bioanal. Chem. 2005, 382, 269-274. [CrossRef]

29. Kendix, E.L.; Prati, S.; Joseph, E.; Sciutto, G.; Mazzeo, R. ATR and transmission analysis of pigments by means of far infrared spectroscopy. Anal. Bioanal. Chem. 2009, 394, 1023-1032. [CrossRef] [PubMed]

30. Farmer, V.C. The Infrared Spectra of Minerals; Mineralogical Society of Great Britain and Ireland: London, UK, 1974.

31. Vahur, S.; Teearu, A.; Leito, I. ATR-FT-IR spectroscopy in the region of $550-230 \mathrm{~cm}^{-1}$ for identification of inorganic pigments. Spectrochim. Acta A Mol. Biomol. 2010, 75, 1061-1072. [CrossRef]

32. Zviagina, B.B.; Drits, V.A.; Dorzhieva, O.V. Distinguishing features and identification criteria for K-dioctahedral $1 \mathrm{M}$ micas (Illite-aluminoceladonite and illite-glauconite-celadonite series) from middle-infrared spectroscopy data. Minerals 2020, 10, 153. [CrossRef]

33. Ekosse, G.-I.E. Fourier transform infrared spectrophotometry and X-ray powder diffractometry as complementary techniques in characterizing clay size fraction of kaolin. J. Appl. Sci. Environ. Manag. 2005, 9, 43-48. [CrossRef]

34. Hahn, A.; Vogel, H.; Andó, S.; Garzanti, E.; Kuhn, G.; Lantzsch, H.; Schüürman, J.; Vogt, C.; Zabel, M. Using Fourier transform infrared spectroscopy to determine mineral phases in sediments. Sediment. Geol. 2018, 375, 27-35. [CrossRef]

35. Khang, V.C.; Korovkin, M.V.; Ananyeva, L.G. Identification of clay minerals in reservoir rocks by FTIR spectroscopy. IOP Conf. Ser. Earth Environ. Sci. 2016, 43, 012004. [CrossRef]

36. Kang, L.; Zhang, M.; Liu, Z.H.; Ooi, K. IR spectra of manganese oxides with either layered or tunnel structures. Spectrochim. Acta A Mol. Biomol. 2007, 67, 864-869. [CrossRef]

37. Siddall, R. Mineral pigments in archaeology: Their analysis and the range of available materials. Minerals 2018, 8, 201. [CrossRef]

38. Eastaugh, N.; Walsh, V.; Chaplin, T.; Siddall, E. Pigment Compendium: A Dictionary and Optical Microscopy of Historical Pigments, 1st ed.; Butterworth-Heinemann: London, UK, 2008.

39. Westlake, P.; Siozos, P.; Philippidis, A.; Apostolaki, C.; Derham, B.; Terlixi, A.; Perdikatsis, V.; Jones, R.; Anglos, D. Studying pigments on painted plaster in Minoan, Roman and Early Byzantine Crete. A multi-analytical technique approach. Anal. Bioanal. Chem. 2012, 402, 1413-1432. [CrossRef]

40. Popelka-Filcoff, R.S.; Robertson, J.D.; Glascock, M.D.; Descantes, C. Trace element characterization of ochre from geological sources. J. Radioanal. Nucl. Chem. 2007, 272, 17-27. [CrossRef]

41. Marcaida, I.; Maguregui, M.; Morillas, H.; Prieto-Taboada, N.; Fdez Ortiz de Vallejuelo, S.; Veneranda, M.; Madariaga, J.M.; Martellone, A.; De Nigris, B.; Osanna, M. In situ non-invasive characterization of the composition of Pompeian pigments preserved in their original bowls. Microchem. J. 2018, 139, 458-466. [CrossRef]

42. Guineau, B.; Lorblanchet, M.; Gratuze, B.; Dulin, L.; Roger, P.; Akrich, R.; Muller, F. Manganese black pigments in prehistoric paintings: The case of the Black Frieze of Pech Merle (France). Archaeometry 2001, 43, 211-225. [CrossRef]

43. Weihe, H.; Piligkos, S.; Barra, A.L.; Laursen, I.; Johnsen, O. EPR of $\mathrm{Mn}^{2+}$ impurities in calcite: A detailed study pertinent to marble provenance determination. Archaeometry 2009, 51, 43-48. [CrossRef]

44. Butterman, W.C.; Reese, R.G.J. Mineral Commodity Profiles-Rubidium; Report/03-045; U.S. Geological Survey: Reston, VA, USA, 2003. [CrossRef]

45. Beck, L.; Rousselière, H.; Castaing, J.; Duran, A.; Lebon, M.; Moignard, B.; Plassard, F. First use of portable system coupling X-ray diffraction and X-ray fluorescence for in-situ analysis of prehistoric rock art. Talanta 2014, 129, 459-464. [CrossRef]

46. Bhattacharyya, P.K.; Dasgupta, S.; Fukuoka, M.; Roy, S. Geochemistry of braunite and associated phases in metamorphosed non-calcareous manganese ores of India. Contrib. Mineral. Petrol. 1984, 87, 65-71. [CrossRef]

47. Cuní, J. What do we know of Roman wall painting technique? Potential confounding factors in ancient paint media analysis. Herit. Sci. 2016, 4, 44. [CrossRef]

48. Tuñón, J.; Sánchez, A.; Parras, D.J.; Amate, P.; Montejo, M.; Ceprián, B. The colours of Rome in the walls of Cástulo (Linares, Spain). Sci. Rep. 2020, 10, 12739. [CrossRef] [PubMed] 
49. Siddall, R. Not a day without a line drawn: Pigments and painting techniques of Roman Artists. Infocus Mag. 2006, 2, 1-14. [CrossRef]

50. Bioucas-Dias, J.M.; Plaza, A.; Dobigeon, N.; Parente, M.; Du, Q.; Gader, P.; Chanussot, J. Hyperspectral unmixing overview: Geometrical, statistical, and sparse regression-based approaches. IEEE J. Sel. Top. Appl. Earth Obs. Remote. Sens. 2012, 5, 354-379. [CrossRef]

51. Rohani, N.; Pouyet, E.; Walton, M.; Cossairt, O.; Katsaggelos, A.K. Nonlinear Unmixing of Hyperspectral Datasets for the Study of Painted Works of Art. Angew. Chemie-Int. Ed. 2018, 57, 10910-10914. [CrossRef]

52. Capobianco, G.; Prestileo, F.; Serranti, S.; Bonifazi, G. Hyperspectral imaging-based approach for the in-situ characterization of ancient Roman wall paintings. Period. Mineral. 2015, 84, 407-418. [CrossRef]

53. de La Rie, E.R. Fluorescence of paint and varnish layers (Part I). Stud. Conserv. 1982, 27, 1-7. [CrossRef]

54. Amadori, M.L.; Barcelli, S.; Poldi, G.; Ferrucci, F.; Andreotti, A.; Baraldi, P.; Colombini, M.P. Invasive and non-invasive analyses for knowledge and conservation of Roman wall paintings of the Villa of the Papyri in Herculaneum. Microchem. J. 2014, 118, 183-192. [CrossRef]

55. Gelzo, M.; Corso, G.; Pecce, R.; Arcari, O.; Piccioli, C.; Dello Russo, A.; Arcari, P. An enhanced procedure for the analysis of organic binders in Pompeian's wall paintings from Insula Occidentalis. Herit. Sci. 2019, 7, 12. [CrossRef]

56. Fantoni, R.; Caneve, L.; Colao, F.; Fiorani, L.; Palucci, A.; Dell’Erba, R.; Fassina, V. Laser-induced fluorescence study of medieval frescoes by Giusto de' Menabuoi. J. Cult. Herit. 2013, 14, S59-S65. [CrossRef]

57. Angheluta, L.; Moldovan, A.; Rădvan, R. The teleoperation of a lif scanning device. UPB Sci. Bull. Ser. A Appl. Math. Phys. 2011, 73, 193-200.

58. Allag, C.; Barbet, A. Techniques de Préparation des Parois Dans la Peinture Murale Romaine; Ecole Française de Rome: Rome, Italy, 1972.

59. Barbet, A. Peinture Murale Romaine Dans Les Provinces De l'Empire, 1st ed.; British Archaeological Reports: Oxford, UK, 1983.

60. Miriello, D.; Barca, D.; Bloise, A.; Ciarallo, A.; Crisci, G.M.; De Rose, T.; Gattuso, C.; Gazineo, F.; La Russa, M.F. Characterisation of archaeological mortars from Pompeii (Campania, Italy) and identification of construction phases by compositional data analysis. J. Archaeol. Sci. 2010, 37, 2207-2223. [CrossRef]

61. Alonso-Olazabal, A.; Ortega, L.A.; Zuluaga, M.C.; Ponce-Antón, G.; Echevarría, J.J.; Fernández, C.A. Compositional characterization and chronology of roman mortars from the archaeological site of arroyo de la dehesa de velasco (Burgo de osma-ciudad de osma, Soria, Spain). Minerals 2020, 10, 393. [CrossRef]

62. Ionescu, C.; Ghergari, L.; T,entea, O. Interdisciplinary (mineralogical-geological-archaeological) study on the tegular material belonging to the legion XIII Gemina from Alburnus Maior (Roșia Montanã) and Apulum (Alba Iulia): Possible raw materials sources. Cercet. Arheol. 2006, 13, 413-436. [CrossRef] 